\title{
Success of banking ombudsmen scheme: Myth or reality
}

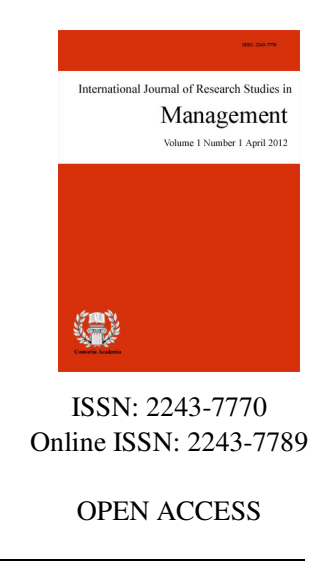

Malyadri, Pacha $\$

Principal, Government Degree College, Andhra Pradesh, India (drpm16@yahoo.co.in)

Sirisha, S.

Lecturer, Institute of Technology and Management, Warangal, Andhra Pradesh, India (sirisha@itm.edu)

\section{Abstract}

In the present banking system, excellence in customer service is the most important tool for sustained business growth. Customer complaints are part of the business life of any corporate entity. This is more so for banks because they are service organizations. Over a period of time, the number of complaints against banks with regard to deficiency of their services has been increasing in spite of several efforts taken by the banks on the advice of the Reserve Bank of India. Since the role of banks has changed from 'Class Bank' to 'Mass Bank', there is a tremendous pressure on the part of banks to satisfy the various needs of the customers. The load of work is increasing day by day on banks taking into account The Banking Ombudsman (BO) Scheme was established by the Reserve Bank of India (RBI) in 1995 to provide speedy solutions to grievances faced by bank customers. Although the number of complaints received through this forum has increased in recent times, the lack of awareness among the customers was a big concern. Through some proactive measures taken by the RBI and awareness campaigns conducted by the Ombudsman, the scenario looks much brighter today. Even then, a lot needs to be done to make the Scheme function more effectively. Against this backdrop, an attempt has been made to analyze the performance of Banking Ombudsman Scheme. Hence, the purpose of the present paper is to analyses the performance of the Banking Ombudsmen.

Keywords: banking performance; banking ombudsman; customer relations; consumer or customer; complaints; grievances 


\section{Success of banking ombudsmen scheme: Myth or reality}

\section{Introduction}

The institution of banking offers opportunity for investors and channelizes the resources available for the growth and sustenance of trade, commerce and industry, and, hence, an efficient banking system is necessary for the growth of the national economy. It is necessary that in such a system checks and balances be introduced to reduce inefficiency and maladministration. Moreover, the quality of the service of the banks depends upon the service provided to the customers and same determines the reputation and growth of the bank. Banking being public utility services and in view of the deteriorating services rendered to the public and also having regard to the fact that services so rendered by banks in irresponsible manner, which are not only inefficient but deficient in character and in the said stress and strain, the public/customer is put pillar to post without having any remedy, it was felt necessary to have a separate fora to receive and resolve such grievances. Of course, the Consumer Protection Act, 1986 or courts, has taken care of it but as of now consumer forum is hard pressed with the alarming rise in number of cases.

In the banking sector, so far consumer or customer are concerned, their grievances are many and varied. Reserve Bank of India (RBI) is flooded with complaints. They received complaint and forward the complaint to concerned bank and banks are required to submit comment and confirm that grievance of the customers stand redressed. Whether it is redressed or not, paper transactions take place. Banking sector is constantly under criticism by press, public and estimate committees. Various committees, commissions and working group were formed to go into the issue since 1972. Banking Commission was headed by Sri R. G. Saraiya followed by Sri. R. $K$. Talwar which made as much as 172 recommendations and lastly report of the Goiporia Committee is a step further as to the sustained anxiety of RBI towards improvement of customer services in banks. Banks have implemented the recommendations to greater extent still there is no perceptible change in the quality of customer services and still the deficient areas are palpably visible and the customer remain dissatisfied. The 'Narasimhan' Committee on "Banking and Financial Sector Reforms" examined these critical areas and recommended introduction of the "Banking Ombudsman Scheme 1995" as a part of Financial Sector Policy and Systems Reforms 1991-92 to 1995-96. Recommendations are very much significant and certainly, it was a needed requirement. This is timely in the changing needs of the customers, in the context of growing liberalization in the banking and financial sectors along with the growing awareness amongst customers, of their rights.

In this background RBI has accepted the recommendation and as a part of banking policy, Dr. $C$. Rangarajan; Governor, announced the "The Banking Ombudsman Scheme" on June 14, 1995. The scheme was issued under the provision of Banking Regulation Act, 1949, covers all Scheduled Commercial Banks and the Scheduled Primary Co-operative Banks having business in India. The Scheme has become operative from June 1995. Initially Ombudsman was appointed on full time basis in three centers i.e. Mumbai, New Delhi, and Bhopal but subsequently its base for operation has been expanded. The aim and objective mechanism of ombudsman is to deliver quick and inexpensive facility to resolve grievances of customers arising out of deficient services rendered by the banks. Hence, banking ombudsman is in place to cater to public complaints against deficiency in banking services concerning operation of deposit accounts and loans and advances. Paradigm Shift of Banking Ombudsman Scheme 1995 to Banking Ombudsman Scheme of 2006; the attempt over years has been to extend the scope and jurisdiction of the Banking ombudsman to hitherto uncovered areas. This has been done in two ways:

1. Coverage of banks: under the 1995 Scheme, only commercial banks and Scheduled Primary Co-operative Banks, having a place of business in India, were covered. Then 2002 Scheme broadened the operation of the ombudsman by including within the definition of 'bank' such entities as Regional Rural Banks, State Bank of India, and 'subsidiary bank' as defined in Part I of the Banking Regulation 
Act, 1949. Even the Scheduled Commercial banks are covered under the latest scheme of 2006.

2. Entertainment of Complaints: the Ombudsman Scheme lays down the grounds on which complaints can be entertained by the Ombudsman. The trend over the year has been to extend the jurisdiction of ombudsman.

The RBI has expanded the scope of the banking ombudsman to include customer complaints relating to credit cards, deficiencies on the part of sales agents of banks to provide promised services, levying service charges without prior notice to the customer and non-adherence to the fair practices code as adopted by individual banks. In order to make the scheme more effective, the RBI has decided to take the onus of recruitment and funding of the scheme. It has also allowed complainants to file their complaints online and appeal to it against the judgments given by the banking ombudsman.

The Banking Ombudsman Scheme, 1995 was notified by RBI on June 14, 1995 in terms of the powers conferred on the Bank by Section 35A of the Banking Regulation Act, 1949 (10 of 1949) to provide for a system of redressal of grievances against banks. The Scheme sought to establish a system of expeditious and inexpensive resolution of customer complaints. The Scheme which is in operation since 1995 has been revised during the year 2002 and 2006. The Scheme is being executed and administered by Banking Ombudsmen appointed by RBI at 15 centers covering the entire country.

\section{Literature review}

The number of studies has been conducted regarding the services of banking ombudsman to their customers. Some of them are listed below:

Goyal and Thakur (2008) concludes that public sector banks that have no monopoly licenses are to be given to new public sector banks and foreign banks. However, when the public sector banks realized that government was no longer there for them, they started devising various strategies for survival and growth. In the present study, the researcher has taken 3 public and private sector banks. Furthermore, Kamakodi (2007) examines how computerization has influenced the banking habits and preference of Indian customers, and which factors influence these preferences. Changing of residence, salary and non-availability of technology based services were given as the three main reasons for changing bank. Jain and Jain (2006) show that the Indian banking industry has undergone radical changes due to liberalization and globalization measures undertaken since 1991 . There has been a great surge in retail banking. The study based on responses received from 200 customers of Housing Development Financial Corporation (HDFC) bank, Industrial Credit and Investment Corporation of India (ICICI) bank and some other private and nationalized banks in Varanasi identified the various types of services offered by banks, the level of satisfaction about different types of services, expectations about these services and the level of segmentation among the services offered.

Shankar (2004) asserts that customer service in banks means satisfying the needs of customers at the right time and in the right manner with accuracy, reliability, high service speed, security and enquiry facility for an efficient customer service. The excellent and managing customer relationship is the future of any business or everybody's business. As such, customer focus is not being viewed as just a business strategy, but should become a corporate mission. The ongoing review shows that a customer's satisfaction of is an invaluable asset for the modern organization. To reduce the complaints, bank should improve service because the survival of banking business is dependent on customer service.

\section{Research objective}

The main objective of the study is to analyze the performance of the Banking Ombudsman Scheme. The present study is based on secondary data. The secondary data were collected from technical books, articles, previous studies, committee reports, Indian Banks Association Bulletin (IBI) bulletins, RBI bulletins, staff 
Malyadri, P. \& Sirisha, S.

training college of the State Bank of India (SBI) and from data relating to banks. The present study is confined to ten years i.e. from 1999-2000 to 2009-2010.

\section{Analytical study of performance of the banking ombudsmen}

The Banking Ombudsman Offices receive complaints pertaining to deficiency in service provided by banks. The number of complaints received by the Banking Ombudsman Offices (BO) has been observed to be steadily increasing since 1999-2000 to 2009-2010 except in the year 2002-03 there was a marginal decrease. Further, the number of complaints received in the year 2005-06 has more than trebled as compared to the year 2004-05. The number of complaints received has increased phenomenally since the revised Banking Ombudsman Scheme 2006. The huge increase in the number of complaints received during the year 2005-06 was on account of the increased scope of the Banking Ombudsman Scheme, 2006. The revised Banking Ombudsman Scheme, 2006 was introduced with effect from January 1, 2006. This Scheme had new areas, such as credit card complaints, within its ambit and facilitated complaint submission in any form including online and by email. Further, a centralized advertising campaign was undertaken by the bank when the new Scheme was introduced. Banking Ombudsman offices effectively addressed 94 per cent of the total complaints received (compared to 87 per cent in the previous year). During 2009-10, the Banking Ombudsmen (BO) received 79, 266 complaints, recording an increase of 15 per cent from 69,117 complaints received in 2008-09. The rate of increase, however, dropped significantly; from $44 \%$ in $2008-2009$ to $15 \%$ in $2009-2010$. The number of complaints increased mainly due to awareness campaigns carried out by the Banking Ombudsmen (BOs) and various proactive measures taken by the Reserve Bank.

Table 1

Number of complaints received by the Banking Ombudsmen (BO)*

\begin{tabular}{ccccc}
\hline Period & $\begin{array}{c}\text { No. of offices of } \\
\text { Banking Ombudsman }\end{array}$ & $\begin{array}{c}\text { Average } \\
\text { complaints/office }\end{array}$ & Annual complaints & $\begin{array}{c}\text { Rate of increase } \\
\text { (\% over previous year) }\end{array}$ \\
\hline $1999-00$ & 15 & 333 & 4994 & - \\
$2000-01$ & 15 & 387 & 5803 & 16 \\
$2001-02$ & 15 & 394 & 5907 & 1 \\
$2002-03$ & 15 & 360 & 5399 & -9 \\
$2003-04$ & 15 & 550 & 8246 & 53 \\
$2004-05$ & 15 & 704 & 10560 & 28 \\
$2005-06$ & 15 & 2115 & 31732 & 200 \\
$2006-07$ & 15 & 2576 & 38638 & 22 \\
$2007-08$ & 15 & 3192 & 47887 & 24 \\
$2008-09$ & 15 & 4608 & 69117 & 44 \\
$2009-10$ & 15 & 5284 & 79266 & 15 \\
\hline Note. *Includes only the complaints received during the year and excludes the number of pending complaints, for example, the leftover \\
complaints from the previous year. \\
Source. Annual report on ombudsman scheme 2004 onwards.
\end{tabular}

The Banking Ombudsman Offices could dispose of more than $70 \%$ of the maintainable complaints on an annual basis except in the year 1999-2000. Despite increase in the number of complaints, the percentage of maintainable complaints disposed off increased steadily except during 2002-03 when it dipped marginally. Again from 2003-04 the number of complaints and the percentage of maintainable complaints disposed off increased. After a slight decrease in the percentage of maintainable complaints in the year 2005-06, there was an increase in the percentage of maintainable complaints disposed of from 2006-07 to 2007-08 but again in the year 2008-09 the percentage of maintainable complaints disposed of reduced from $83 \%$ to $70 \%$ and in the year $2009-10$ it increased to $85 \%$. As the sudden increase in the number of complaints could not be matched by equivalent rise in disposal of complaints, the number of pending complaints also increased. As regards pendency, the number of 
Success of banking ombudsmen scheme: Myth or reality

complaints pending is around $\mathbf{1 6 \%}$ to $\mathbf{1 9 \%}$ of the total complaints dealt during the year 2009-10.

Table 2

Disposal of complaints by Banking Ombudsmen

\begin{tabular}{|c|c|c|c|c|c|c|c|c|c|}
\hline Period & $\begin{array}{c}\text { Complaints } \\
\text { received }\end{array}$ & $\begin{array}{c}\text { Complaints } \\
\text { brought } \\
\text { forward }\end{array}$ & $\begin{array}{l}\text { Total* } \\
\text { complaints } \\
\text { received }\end{array}$ & $\begin{array}{l}\text { Complaints } \\
\text { not } \\
\text { maintainable }\end{array}$ & $\begin{array}{l}\text { Complaints } \\
\text { maintainable }\end{array}$ & $\begin{array}{c}\text { No. of } \\
\text { maintainable } \\
\text { complaints } \\
\text { disposed of } \\
\end{array}$ & $\begin{array}{c}\% \text { of } \\
\text { maintainable } \\
\text { complaints } \\
\text { disposed of } \\
\end{array}$ & Pending & $\%$ Pending \\
\hline 1999-00 & 4994 & 1806 & 6800 & 2614 & 4186 & 2484 & 60 & 1702 & 25 \\
\hline 2000-01 & 5803 & 1175 & 6978 & 2732 & 4246 & 3131 & 74 & 1115 & 16 \\
\hline 2001-02 & 5907 & 1115 & 7022 & 2404 & 4618 & 3511 & 76 & 1107 & 16 \\
\hline $2002-03$ & 5399 & 1107 & 6506 & 2132 & 4374 & 3137 & 72 & 1237 & 19 \\
\hline 2003-04 & 8246 & 1237 & 9483 & 4011 & 5472 & 3998 & 73 & 1474 & 16 \\
\hline 2004-05 & 10560 & 1474 & 12034 & 4963 & 7071 & 5440 & 77 & 1631 & 14 \\
\hline $2005-06$ & 31732 & 1631 & 33363 & 12304 & 21059 & 14889 & 70 & 6170 & 18 \\
\hline 2006-07 & 38638 & 6128 & 44766 & 15511 & 29255 & 22150 & 76 & 7105 & 16 \\
\hline 2007-08 & 47887 & 7105 & 54992 & 19735 & 35257 & 29365 & 83 & 5892 & 11 \\
\hline 2008-09 & 69117 & 5892 & 75009 & 43115 & 31894 & 22461 & 70 & 9433 & 13 \\
\hline $2009-10$ & 79266 & 9433 & 88699 & 51847 & 36852 & 31489 & 85 & 5363 & 6 \\
\hline
\end{tabular}

Note. *Includes previous year's complaints.

Source. Annual report on ombudsman scheme 2004 onwards.

Table 3

Complaints dealt with bank (list-wise)

\begin{tabular}{|c|c|c|c|c|c|c|c|c|}
\hline Period & Nationalized Banks & SBI Group & $\begin{array}{l}\text { Private Sector } \\
\text { Banks }\end{array}$ & Foreign Banks & $\begin{array}{c}\text { Scheduled } \\
\text { Primary Coop. } \\
\text { Banks }\end{array}$ & $\begin{array}{l}\text { Regional Rural } \\
\text { Banks(RRBS) }\end{array}$ & Others* & Total \\
\hline 1999-00 & $3857(57 \%)$ & $1960(28 \%)$ & $417(6 \%)$ & $198(3 \%)$ & $131(2 \%)$ & -NA- & $237(4 \%)$ & $6800(100 \%)$ \\
\hline 2000-01 & $3657(52 \%)$ & $2175(31)$ & $531(8 \%)$ & $147(2 \%)$ & $122(2 \%)$ & -NA- & $346(5 \%)$ & $6978(100 \%)$ \\
\hline 2001-02 & $3609(52 \%)$ & $2112(30 \%)$ & $629(8 \%)$ & $254(4 \%)$ & $55(1 \%)$ & -NA- & $363(5 \%)$ & $7022(100 \%)$ \\
\hline 2002-03 & $3145(48 \%)$ & 1914(29\%) & $718(11 \%)$ & $313(5 \%)$ & $112(2 \%)$ & $33(1 \%)$ & $271(4 \%)$ & $6506(100 \%)$ \\
\hline 2003-04 & $4049(43 \%)$ & $2779(28 \%)$ & $1325(14 \%)$ & $406(5 \%)$ & $166(2 \%)$ & $232(2 \%)$ & $526(6 \%)$ & $9483(100 \%)$ \\
\hline 2004-05 & $5124(43 \%)$ & $3359(28 \%)$ & $1863(15 \%)$ & $577(5 \%)$ & $256(2 \%)$ & $359(3 \%)$ & $496(4 \%)$ & $12034(100 \%)$ \\
\hline $2005-06$ & $10137(30 \%)$ & $9892(29 \%)$ & $6754(21 \%)$ & $2997(9 \%)$ & $198(1 \%)$ & $794(2 \%)$ & $2591(8 \%)$ & $33363(100 \%)$ \\
\hline 2006-07 & $10543(27 \%)$ & $11117(29 \%)$ & $9036(22 \%)$ & $3803(10 \%)$ & $313(1 \%)$ & $536(2 \%)$ & $3290(9 \%)$ & $38638(100 \%)$ \\
\hline 2007-08 & $12033(25 \%)$ & $13532(28 \%)$ & $14077(29 \%)$ & $6126(13 \%)$ & $295(1 \%)$ & $826(2 \%)$ & $998(2 \%)$ & $47887(100 \%)$ \\
\hline 2008-09 & $14974(21 \%)$ & $18167(25 \%)$ & $21982(31 \%)$ & $11700(17 \%)$ & $302(1 \%)$ & $846(2 \%)$ & $1146(3 \%)$ & $69117(100 \%)$ \\
\hline $2009-10$ & $19092(24 \%)$ & $22832(29 \%)$ & $22553(28 \%)$ & $11450(14 \%)$ & $183(1 \%)$ & $785(2 \%)$ & $2371(3 \%)$ & $79266(100 \%)$ \\
\hline
\end{tabular}

Note. *Institutions not covered under the scheme. Figures in brackets indicate percentage of each bank group to the total number of banks. Source. Annual report of banking ombudsman scheme 2004 onwards.

The above table reveals the complaints received by Banking Ombudsman against different bank groups. The majority of the complaints pertain to the Nationalized Banks followed by the State Bank Group, constituting around $70-85 \%$ of the complaints received from the year 1999-2000 to 2004-2005. However, from the year 2005-06, the increase in the percentage of complaints and the number of complaints received against private sector banks and foreign banks, indicating probably that the private sector banks and foreign banks had many complaints falling under the new grounds of complaints added in the BO Scheme, 2006. The RRBs were brought under the purview of the Banking Ombudsman from the year 2002 as per Banking Ombudsman Scheme (BOS) 2002 and predictably the number of complaints against RRBs increased from 33 during the year 2002-2003 to 232 in the year 2009-2010. Increasing number of complaints against RRBs indicate the penetration of the Scheme in rural areas. Private sector banks and foreign banks have been heavy users of cutting-edge banking technology and are leading branchless banking initiatives. It is concerning that technology-intensive banks generate a much higher level of complaints when compared with low-technology banks. According to report, in 
Malyadri, P. \& Sirisha, S.

2008-09 the number of complaints against foreign banks has risen by $91 \%$ from a year ago which shows that Indian customers are most dissatisfied with the foreign banks carrying out operations in India.

\section{Table 4}

Cost details of Banking Ombudsman Offices

\begin{tabular}{cccccccc}
\hline Period & $\begin{array}{c}\text { Total Cost } \\
\text { (Rs) }\end{array}$ & $\begin{array}{c}\text { No. of } \\
\text { Complaints } \\
\text { dealt }\end{array}$ & $\begin{array}{c}\text { Cost per } \\
\text { complaint } \\
\text { (Rs) }\end{array}$ & $\begin{array}{c}\text { No. of } \\
\text { maintainable } \\
\text { complaints } \\
\text { dealt }\end{array}$ & $\begin{array}{c}\text { Cost per } \\
\text { maintainable } \\
\text { complaint } \\
\text { (Rs) }\end{array}$ & $\begin{array}{c}\text { No. of } \\
\text { Complaints } \\
\text { disposed }\end{array}$ & $\begin{array}{c}\text { Cost per } \\
\text { complaint } \\
\text { (Rs) }\end{array}$ \\
\hline $1999-00$ & 6.15 & 6800 & 9050 & 4186 & 14692 & 5098 & 12063 \\
$2000-01$ & 6.99 & 6978 & 10020 & 4246 & 16463 & 5863 & 11922 \\
$2001-02$ & 5.91 & 7022 & 8416 & 4618 & 12,798 & 5915 & 9991 \\
$2002-03$ & 6.36 & 6506 & 9776 & 4374 & 14540 & 5269 & 1207 \\
$2003-04$ & 7.03 & 9483 & 7413 & 5472 & 12847 & 8009 & 8777 \\
$2004-05$ & 7.6 & 12034 & 6315 & 7071 & 10748 & 10403 & 7305 \\
$2005-06$ & 8.12 & 33363 & 3045 & 21059 & 3856 & 27193 & 2986 \\
$2006-07$ & 9.81 & 38638 & 2538 & 29255 & 3353 & 37661 & 2605 \\
$2007-08$ & 12.50 & 47887 & 2611 & 35257 & 3545 & 49100 & 2546 \\
$2008-09$ & 15.29 & 69117 & 2212 & 31894 & 4794 & 65576 & 2331 \\
$2009-10$ & 19.74 & 79266 & 2490 & 36852 & 5357 & 83336 & 2369 \\
\hline
\end{tabular}

Source. Annual report on ombudsman scheme 2004-10.

The costs of the Scheme include the revenue expenditure and capital expenditure incurred in running the BO offices. The revenue expenditure includes the establishment items like salary and allowances of the staff attached to BO offices and non-establishment items such as rent, taxes, insurance, law charges, postage and telegram charges, printing and stationery expenses, publicity expenses, depreciation and other miscellaneous items. The capital expenditure items include the furniture, electrical installations, computers/related equipments, telecommunication equipments and motor vehicle. The total annual costs of running the fifteen Banking Ombudsman offices (15 BO offices) have been increasing steadily from 1999-00 to 2009-10 except in the year 2001-02. However, with the increase in the number of complaints dealt, the cost per complaint dealt as well as cost per maintainable complaint have been steadily decreasing with the amount at Rs. 2,538 for the year 2009-10. While the cost of running the Scheme through 15 offices of BO in the country at Rs. 19.74 recorded an increase of $29 \%$ over the previous year, the average cost per complaint remained at Rs. 2368 - the same level as that of the last year. This was due to increase in the number of complaints received/dealt with.

Table 5

Mode wise receipt of complaints

\begin{tabular}{ccccc}
\hline Period & Email & Online & Others & Total \\
\hline $2007-08$ & $7183(15 \%)$ & $7662(16 \%)$ & $33042(69 \%)$ & $47887(100 \%)$ \\
$2008-09$ & $15927(23 \%)$ & $9352(14 \%)$ & $43838(63 \%)$ & $69117(100 \%)$ \\
$2009-10$ & $9221(12 \%)$ & $11400(14 \%)$ & $58645(74 \%)$ & $79266(100 \%)$ \\
\hline
\end{tabular}

Source. Annual report on ombudsman scheme 2008-10.

The Banking Ombudsman Scheme, 2002 was revised and the Banking Ombudsman Scheme, 2006 came into force with effect from January 1, 2006. The scope of the Scheme has been enlarged and the Scheme provides for on-line submission of complaints. Complainants can $\log$ on to the Reserve Bank web site at www.rbi.org.in and complain about deficiency in bank's services by using the online complaint form. The email ids of the Banking Ombudsmen are also available in the public domain and complainants can send emails to them. For those who have no access to internet, complaints can be sent by post and in any language. Complaints 
Success of banking ombudsmen scheme: Myth or reality

received are acknowledged and tracked till they are closed in the book of the Office of the Banking Ombudsman. Though others mode of complaints received are higher in all the years the receipt in the electronic mode has been slowly picking up. In the year 2007-08 $69 \%$ of complaints received through letters, post-cards etc, and email complaints increased from $15 \%$ to $23 \%$ of the total complaints between 2007-08 and 2008-09. During the Year 2009-10, indication shows the less access to internet facilities in the rural/semi urban areas as compared to the urban and metro. Email complaints have decreased from $23 \%$ to $12 \%$ of the total complaints. Since $47 \%$ of the complaints are received from the rural (32\%) and semi-urban (15\%) areas, the receipt of complaints through the postal mode has increased from $63 \%$ to $74 \%$ during the year $2009-10$, indicating the less access to internet facilities in the rural/semi urban areas as compared to the urban and metro. Email complaints have decreased from $23 \%$ to $12 \%$ of the total complaints during the year $2009-10$.

\section{Table 6}

Geographical distribution of complaints

\begin{tabular}{ccccc}
\hline Period & Rural & Semi-urban & Urban & Metropolitan \\
\hline $2007-08$ & $8418(18 \%)$ & $6641(13 \%)$ & $10978(23 \%)$ & $21850(46 \%)$ \\
$2008-09$ & $13915(20 \%)$ & $9817(14 \%)$ & $15723(23 \%)$ & $29662(43 \%)$ \\
$2009-10$ & $25055(32 \%)$ & $10741(15 \%)$ & $16423(20 \%)$ & $27047(33 \%)$ \\
\hline
\end{tabular}

Note. Figures in brackets indicate percentage of each bank group to the total number of banks.

Source. Annual report on ombudsman scheme 2008-2010.

The offices of the Banking Ombudsman received complaints from almost all the regions of the country. An analysis of the complaints received and settled by the banking Ombudsman offices reveals that the number of complaints increased in 2007-08 over 2006-07 in absolute figures as well as In percentage but when we compare the performance of 2009-10 over 2008-09 the number of complaints increased in absolute figures but where as in the case of percentage it has been decreased, for example, the growth rate of complaints decreased in 2009-10 as compared to 2008-09. The number of complaints filed with the Ombudsman is relatively small compared with the vast banking sector and the millions of customers using banking services. There seems to be little awareness of the Ombudsman scheme and how to access an Ombudsman office. The urban-centric nature of the offices and the level of literacy required to file grievances also impede easy access. Data on complaints with the Ombudsman show a relatively large number of complaints from urban and metropolitan areas. The reasons for larger number of complaints from the urban and metropolitan regions are increased penetration of banking, increased awareness and increased expectations of customers in such areas. However, there is evidence that there is increase in the receipt of complaints from rural and semi urban areas, as the Banking Ombudsman have created more awareness in such areas through personal visits, media coverage and advertisements. The offices of the Banking Ombudsmen received increasing number of complaints from urban and metropolitan areas during the year 2007-08 and 2008-09; whereas in the year 2009-10 the offices of the Banking Ombudsmen received increasing number of complaints from rural and metropolitan. The number of complaints from rural and metropolitan areas increased during the year 2009-10. Complaints received from metropolitan areas constituted $34 \%$ of total complaints, followed by rural areas at $32 \%$, urban areas at $20 \%$ and semi-urban areas at $14 \%$. This was mainly due to the awareness efforts undertaken by the Banking Ombudsmen as well as the Reserve Bank through personal/ village visits, media campaign, and many others.

\section{Conclusion}

Deregulation and information technology initiatives in banking sector have given competitive advantage to banks in India. Present thinking is that competition would take care of consumer welfare more than any other legislative measure. This apart, the ombudsman should demonstrate its impartiality for consumer protection to win the confidence of small consumers. Retired executives of banks and financial Institutions with some legal and practical background would be most eligible for the post of ombudsman. There is a need to give some sort of 
legal backing to the ombudsman scheme in India. If the scheme is codified and the ombudsman given the powers of an ordinary court of law, viz., the power to summon witnesses, to call for disclosure of any document or information, to conduct an inquiry etc. Will greatly facilitate is working. Most importantly, the Ombudsman must be given powers of contempt because without this, all concerned ca flout the directives of the ombudsman. To instill consumer confidence in the scheme, the RBI has to ensure that the awards of the ombudsman are implemented by the banks.

Thus, it can be seen that the Ombudsman scheme is a boon and a very important channel for redressal of grievances by the general public against banks and banking services. It is framed in such a manner that it does not oust the jurisdiction of other courts, and hence, aggrieved people do not hesitate in using the banking ombudsman as a primary forum for resolution of disputes regarding banks. The hallmark of the banking ombudsman probably is that it is in position to do justice in an individual case, in the sense it is not bound by the precedents and in certain circumstances, can ignore technicalities and legal rules of evidence while resolving disputes between aggrieved customer and the bank. Apart from above BO's offices have also started outreach activities for creating awareness among customers like interface with banks, organizing awareness camps, participation in exhibitions, responding to readers' queries in newspapers, broadcasting advertisements through AIR and Doordarshan and many others.

About the author: Dr. P. Malyadri has got 27 years of experience of Teaching, Research, Administration, Training, and consultancy. A prolific writer; Dr. Malyadri has published 4 Books and 57 research papers on Banking, Rural and economic development issues in various National and International journals of repute. $\mathrm{He}$ has presented several research papers in around 80 National and International seminars and conferences. He is an Active member in Editorial advisory boards of 55 international journals published from Canada, USA, Taiwan, Czech Republic, Italy, Turkey, Dubai, Philippines, Australia, Bangladesh, Pakistan, Africa, and many others; and 13 national journals of repute. Dr. Malyadri carried out two Major Research Projects sponsored by the UGC, New Delhi. He is a recognized Research supervisor to guide M.Phil. and Ph.D. students in the Departments of Commerce and Business Management, Osmania University and was awarded 3 Ph.D.'s and 22 M.Phil.'s under his guidance. He served as Program officer of the National Service Scheme for 5 years and conducted several programs and received outstanding awards. Presently he is serving as the Principal; Osmania University affiliated college for the last 3 years. He received several outstanding awards for his academic achievements. Dr. Malyadri is a State level Best Teacher awardees in the year 2008, honored by Government of Andhra Pradesh.

\section{References:}

Bhaskar, P. V. (2004). Customer service in banks. IBA Bulletin, 36(8), 9- 13.

Ganesh, C., \& Varghese, M. E. (2003). Customer service in banks: An empirical study. Vinimaya, 36(2), 14-26.

Goyal, S., \& Thakur, K. S. (2008). A study of customer satisfaction public and private sector banks of India. Journal of Business Studies, 3(2), 121-127.

Hasanbanu, S. (2004). Customer service in rural banks: An analytical study of attitude of different types of customers towards banking services. IBA Bulletin, 36(8), 21-25.

Jain, A. K., \& Jain, P. (2006). Customer satisfaction in retail banking services. Journal of Business Studies, 1(2), 95-102.

Kamakodi, N. (2007). Customer preferences on e-banking services: Understanding through a sample survey of customers of present day banks in India contributors. Banknet Publications, 4, 30-43.

Mishra, J. K., \& Jain, M. (2007). Constituent dimensions of customer satisfaction: A study of nationalized and private banks. Prajnan, 35(4), 390-398.

Shankar, A. G. (2004). Customer service in banks. IBA Bulletin, 36(8), 5-7.

Singh, S. (2004). An appraisal of customer service of public sector banks. IBA Bulletin, 36(8), 30-33.

Singh, S. B. (2006). Customer management in banks. Vinimaya, 37(3), 31- 35.

Uppal, R. K. (2010). Customer complaints in banks: Nature, extent and strategies to mitigation. Journal of Economics and International Finance, 10, 212-220. 